\title{
Demographic Characteristics and Buyers Purchase Decision of Two Wheeler Brands in Bagmati Province, Nepal
}

\author{
Makshindra Thapa, $P h D$ \\ Lecturer, Tribhuvan University \\ Visiting Faculty, Nesfield International College \\ Email: tmakshindra@yahoo.com
}

\begin{abstract}
The purpose of this paper is to analyze buyers' demographic characteristics that influence purchasing decisions of two wheelers brands available in the Nepalese market. The survey study was conducted in the four districts of Bagmati province. Altogether, opinions of 208 respondents were included in the study to express their assertion of two wheeler purchasing decisions. Cross tabulation was done to identify patterns of demographic (categorical) variables and two wheeler brands. The chi-square analysis was done to examine associations between demographic variables and purchase decisions of two wheeler brands. The results of chi-square analysis indicated that buyers' gender, age, education and occupation have highly significant association with purchase decision. Similarly, income level and marital status are significantly associated with purchase decision. The various categories of demographic characteristics analyzed in the study influence buyer two wheeler brand purchase decisions.
\end{abstract}

Keywords: consumer buying behavior, buying decisions, demographic factors, buyer's black box model, chi-square test

\section{Background}

The understanding of buyer behavior is the driving force behind any marketing process and this process involves in understanding why and how people decide to purchase particular product or customer loyalty towards brands. Nowadays more focus is being given to study the importance of consumer behavior in marketing. The business environment is increasingly changing and it is very difficult for companies to fight for customer and market share (Khaniwale, 2014). The success of marketing process is to improve understanding about customer preferences and determinants those influence purchasing decisions that help to improve business model and acquiring more customers, each company must adapt to changes in the market to survive.

Consumer buying behavior determines their buying decision. Khaniwale (2014) has mentioned main decisions for the consumer as: what he buys (which products and services), how much (amount), where (place of purchase), the time spent shopping and 
payment methods. Belch and Belch (2004) have stated consumer buying behavior as a complex process that involves a variety of activities including: search, selection, purchase, use, evaluation of products and services to meet their needs and desires. In fact, it is the process; thoughts, feelings and actions related to consumption process of particular product. It refers to the decision and acts people undertake to buy products or services for individual or group use. Several internal and external factors, which can range from short-term to long-term emotional feelings, are affecting customer behavior (Hirschman, 1985).

Consumer buying behavior analysis is an inevitable area of management process. A clear understanding of buying behavior enables firms 'best fit their products' with consumer aspirations thus, maximizing their satisfaction and retention. Consequently, consumer behaviour analysis is useful in estimating the potential size of a market, in market segmentation, in locating preferred trends in product development, in finding out attributes of alternative communication methods and in formulating the most favored marketing mix to secure favorable buyer's response in purchase and repurchase of products. Companies must be familiar with their customers' needs and their purchasing decisions (Puska, Stojanovic, Sadic, \& Becic, 2018). In this relation, the study of consumer behavior specifically consumer buying behavior stays at central core of marketing decisions.

The analysis of customer buying behavior involves in the drives and background of consumer those enforce in purchasing particular product. Consumer's demographic context is one of the key determinants among various factors affecting consumer buying decision. Solomon (2016) argues demographics as statistics that gauge observable aspects of a population like customer birth rate, age, and income. Due to the use of demographic data in locating, predicting, and segmenting the market for many products from home mortgages to can openers, marketers are interested in changes and trends of demographics (Solomon, 2016). Many authors have reported a meaningful relationship between demographics and environmental behaviors; demographics include age, gender, education level, occupation, income level and family size (Bekhet \& Al-alak, 2011; Sang \& Bekhet, 2015; Yau, 2012; Yuan \& Zuo, 2013; Zhao, Gao, Wu, Wang, \& Zhu, 2014; Hassani, 2018; Leila \& Zohra, 2018; Mastaran, 2017; Chhong, 2016).

In the context of Nepal, private automobiles are becoming necessary product due to insufficient provision of public transport facilities. As there is a remarkable shift in occupational and employment patterns of people of urban, sub-urban and even rural area, the demand of private vehicles increasing day by day, private vehicles have become a necessity and a part of social life of people. In Nepalese automobile market, many 
esteemed international brands are competing in various segments of four wheeler and two wheeler markets. Due to ever increasing customer expectation and competition among brands, distributors of such vehicle face pressure in order to assimilate customer context and their offerings. At present two wheelers are most used vehicles in urban and rural sections as they are affordable to customers than of four wheelers. Many foreign brands as Honda, Yamaha, Bajaj, Suzuki, Royal Enfield etc. are offering varieties of premium to entry level bike models as to meet customer requirements and interests. As consumer buying behavior is a complex concept, various factors stimulating their decisions are to be well understood.

\section{Objectives of the study}

This paper aims in describing demographic characteristics of the respondents in terms of gender, age, education, occupation, income, and marital status and brands of two wheelers purchased. Moreover, to examine influence of these demographic factors on two wheeler purchase decision is other key objectives of the study.

\section{Review of the Literature}

\section{The black box model of consumer buying purchasing decision}

Individual purchasing decisions differ from one other and the reason is to be found in the factors that influence consumer buying behaviour. One part of these factors is the buyer's characteristics which affect what is going on in the buyer black box. The buyer black box is the consumer's head which processes stimuli and takes purchase decision. The black box model explains interaction of various factors or stimuli that determine individual buying decisions.

The black box model shows the interaction of stimuli, consumer characteristics, and decision process and consumer responses. It can be distinguished between inter personal stimuli (between people) or intrapersonal stimuli (within people). The marketing stimuli are planned and processed by the companies, whereas the environmental stimulus is given by social factors, based on the economical, political and cultural circumstances of a society. The buyer's black box contains the buyer characteristics and the decision process, which determines the buyer's response (Chauhan, 2013).

According to the model, consumer buying behaviour is affected by four factors: cultural, social, personal and psychological characteristics of buyers. The first factor is cultural factors which constitute of the set of basic values, perceptions and behaviors that distinguish one group from another. These values and behaviors are learned by a member of society from family and other institutions. They are so deep-seated that they steer a 
person in any situation. Therefore, culture is the most fundamental cause of a person's wants and behaviors. Similarly, each culture consists of several smaller subcultures. These subcultures are groups of people who share value systems. This may be based on common experiences and situations. Subcultures can be nationalities, religions, but also geographic regions.

The second factor of the model, social factor implies for the combination of several factors such as income, occupation and education determine the social class structure. The social factors influence the Buyer Black Box includes reference groups, family and roles and status. Among these, families have strongly influence on the buyer black box. In fact, the family size and background are often the most powerful influences on consumer buying behaviour. The marital status and the husband-wife relationship and involvement may greatly affect an individual's buying behaviour. In addition, the Buyer Black Box is greatly influenced by personal characteristics as well. Under which age and lifecycle stage of people, occupation, economic situation, lifestyle, and personality determine choice and purchase behaviors. Finally, the Buyer Black Box is influenced by psychological factors which are purely personal in nature. It includes buyer's motivation, perception, learning, attitude, beliefs etc.

\section{Association between consumer demographic factors and buying decision}

Consumers differ in their behavior and preferences and it is important for marketers to examine these differences based on demography (Vilcekova \& Sabo, 2013).

Demographic characteristics play an important role in consumer's purchase decision process and can cause deviation from general patterns of consumer decision making. Therefore marketers need detailed information about consumers so that they understand their behavior and needs. Obviously, marketers cannot change or control these demographic factors associated with consumers. However, through better understanding of these factors, they can design their offerings in a way that is attractive and matching with consumer real needs.

Many previous studies have analyzed relation on demographic variables of customers with purchase decision in context of different countries and product context. Akpinar et al. (2009) focused on the consumer preferences by analyzing the correlation between socio-economic, demographic profiles and the criteria applied in fresh fruit and vegetable purchasing decisions in Turkey. Their findings gave important hints as to the positive impact of the gender distribution of the population and that of the rise in income and education levels of the consumers on the production and marketing conditions of fresh fruit and vegetables. Further, Cheong (2016) found mixed associations between demographic factors and consumers' reliance on brand-related decisions. Age, gender, 
marital status, number of children in a household, and employment status showed significant associations, whereas education, household income, and ethnicity did not.

The empirical study was conducted in the region of northeast of Bosnia Herzegovina by Puska et al. (2018) which explored the way in which demographic characteristics influence purchasing decisions with focus on high priced technical products including household appliances, computers, TV sets and similar technical products. The results of multivariate analysis of variance (MANOVA) showed that age, gender, income level and employment status of the respondents significantly influences purchasing decisions among consumers. Similarly, Leila and Zohra (2018) conducted research with purpose to identify the effect of demographic factors on the purchasing intent of the local food product in the city of Bechar, Algeria. They found no effect of demographic factors on the purchasing intent of the domestic food product.

Rahim et al. (2017) used consumers' demographic profiles, such as age, gender, income, education background, and occupation to investigate their influences on consumers' green product purchase intention in Malaysia. The results of the study showed that there is a statistically significant difference between gender on consumers' green product purchase intention. Meanwhile, the results generated by ANOVA indicated that there are no significant differences between age, income, education background and occupation on consumers' green product purchase intention. Weerasiri and Mendis ( 2015) collected data from four districts of Sri Lanka from two wheeler users and non-users who are having either two wheeler or willing to have a two wheeler. The result of their study found positive and significant effect of the demographic factors such as age, gender, income level, education level on the purchasing decisions of the two wheelers.

The study of Mastaran (2017) attempted to examine the relationship and impacts of demographic and life style variables with brand choice. With psychographic determinants, she used age, education level, profession and gender of customers as demographic independent variables and brand choice including innovation, quality, advertising, and price and reference group as dependent variable. The results indicated that the lifestyle factors and demographic factors have impact on brand choice variables. Vilcekova and Sabo (2013) used 1067 Slovak consumers' opinions and their attitudes toward brands across gender, age and education. They examined impact of demographic factors on consumers' brand perception. They confirmed that gender does not affect consumers' opinions however; age groups and education levels produced significant differences in brand buying behavior.

Hassani (2018) conducted study on the relationship between demographic factors and green or socially conscious behavior by considering opinions of 76,000 survey responses 
from 18 countries between 2007 to 2013 . The researcher analyzed responses of the detailed survey using Chi square tests to investigate the existence of any relationship between demographic factors (including gender, age, income, level of education, country, and year) and the degree to which a consumer actively punishes or rewards a company based on social responsibility. The findings showed there is a relationship between the studied demographic factors and the consumers' propensity; however only the factor of country showed a strong association, other analyzed variable associations were weak.

\section{Model and Hypothesis}

The theoretical model of the study is based on the black box model of consumer buying purchasing decision. The model defines customer purchase decision as interaction of various factors or stimuli that determine individual buying decisions. The interaction happens among four components- stimuli, consumer characteristics, and decision process and consumer responses. Similarly, the model has highlighted to some stimuli like cultural, social, personal and psychological factors characteristics of the buyer. These social and personal characteristics constitute customer's age, gender, income level, occupation, education, marital status, family size and many other demographic factors.

The conceptual model of the study comprised of independent variables as customer demographic factors; age, gender, education, occupation, marital status and monthly income. Similarly dependent variable constitutes of the two wheeler purchase decision. Based on the model, six hypotheses were constructed as;

$\mathrm{H}_{1}$ : Gender is associated significantly with purchase decision of two wheelers.

$\mathrm{H}_{2}$ : Age is associated significantly with purchased decision of two wheelers.

$\mathrm{H}_{3}$ : Education has a significant association with purchased decision of two wheelers.

$\mathrm{H}_{4}$ : Occupation is associated significantly with purchased decision of two wheelers.

$\mathrm{H}_{5}$ : Income has a significant association with purchased decision of two wheelers.

$\mathrm{H}_{6}$ : Marital status is associated significantly with purchased decision of two wheelers.

\section{Methods}

The study applies descriptive research design as to meet aim of the study in order to examine consumer behavior with respect to decision-making process of two wheelers. The sample respondents constitutes owners of two wheelers within four districts of 
Bagmati province; Kavre, Kathmandu, Bhaktapur, and Lalitpur. Since unavailability of exact number of total two wheeler owners and physical constraints, the snowball sampling techniques has been applied. An online based questionnaire survey was conducted using social media sites. A total of 300 set of questionnaire were distributed and 208 useful responses received representing response rate of 69.33 percent. The survey was administered during December 2020 to February 2021.

The questionnaire was constructed on the light literatures in the area and previous studies (Beatty \& Smith, 1987; Jeyakumar \& Paul Robert, 2010; Bui, Krishen \& Bates, 2011; Waheed, Mahasan \& Sandhu, 2014; Puska, Stojanovic, Sadic, \& Becic, 2018). The questionnaire consisted of two parts. The first part contained general questions about demographic characteristics of respondents: gender, age, education, occupation, household income, and marital status. Similarly, the second part of the questionnaire contains purchase decisions related statements. The demographic variables were categorized as per their nature as depicted in Table 1.

Table 1

The Categories of Demographic Variables Used in the Study

\begin{tabular}{|c|c|c|c|c|c|c|}
\hline Variables & Gender & $\begin{array}{l}\text { Age (in } \\
\text { years) }\end{array}$ & Education & Occupation & $\begin{array}{l}\text { Monthly } \\
\text { Income(NPR) }\end{array}$ & $\begin{array}{l}\text { Marital } \\
\text { status }\end{array}$ \\
\hline \multirow[t]{4}{*}{ Categories } & $1=$ Male & $1=16-25$ & $\begin{array}{l}1=\text { Intermediate } \\
\text { and below }\end{array}$ & $1=$ Students & $\begin{array}{l}1=\text { Less than } \\
20000\end{array}$ & $1=$ Married \\
\hline & \multirow[t]{3}{*}{$2=$ Female } & $2=26-35$ & $2=$ Bachelor & $2=$ Service & $\begin{array}{l}2=20001- \\
40000\end{array}$ & $2=$ Unmarried \\
\hline & & $3=36-45$ & $\begin{array}{l}3=\text { Master and } \\
\text { above }\end{array}$ & $\begin{array}{l}3=\text { Self- } \\
\text { employed }\end{array}$ & $\begin{array}{l}3=40001- \\
60000\end{array}$ & \\
\hline & & $\begin{array}{l}4=46 \text { and } \\
\text { above }\end{array}$ & & & $\begin{array}{l}4=\text { More than } \\
60000\end{array}$ & \\
\hline
\end{tabular}

Statistical analysis of the data was done by using the SPSS software. Specifically, within SPSS, chi-square test of independence was the primary mode of analysis used to determine associations between the independent and dependent variables. This type of test was selected because chi-squared tests are particularly useful in determining relationships between categorical variables (Greenwood \& Nikulin, 1996). A chi square test was calculated to test study hypotheses related to each demographic characteristics and consumer purchase decisions.

\section{Results and Discussion}

The demographic characteristics of the respondents in this study are the focal study dimension which supposed to have significant association with purchase decision. The 
literature review provided evidence of effect of demographic factors on purchase decisions of various products across the globe. Table 2 depicts frequency of the demographic factors considered in the study.

Table 2

Profile of the Demographic Characteristics of the Participants of Survey

\begin{tabular}{|c|c|c|}
\hline Characteristics & Frequency & Percent \\
\hline \multicolumn{3}{|l|}{ Gender } \\
\hline Male & 113 & 54 \\
\hline Female & 95 & 46 \\
\hline Total & 208 & 100 \\
\hline \multicolumn{3}{|l|}{ Age group } \\
\hline $16-25$ & 83 & 39.9 \\
\hline $26-35$ & 101 & 48.56 \\
\hline $36-45$ & 17 & 8.17 \\
\hline 46 and above & 7 & 3.37 \\
\hline Total & 208 & 100 \\
\hline \multicolumn{3}{|l|}{ Education } \\
\hline Intermediate and below & 6 & 17.31 \\
\hline Bachelor & 82 & 39.42 \\
\hline Master and above & 90 & 43.27 \\
\hline Total & 208 & 100 \\
\hline \multicolumn{3}{|l|}{ Occupation } \\
\hline Students & 60 & 28.85 \\
\hline Service & 98 & 47.11 \\
\hline Self-employed & 50 & 24.04 \\
\hline Total & 208 & 100 \\
\hline \multicolumn{3}{|l|}{$\begin{array}{l}\text { Household Income } \\
\text { (NPR./month) }\end{array}$} \\
\hline Less than 20000 & 85 & 40.86 \\
\hline $20001-40000$ & 71 & 34.14 \\
\hline $40001-60000$ & 26 & 12.5 \\
\hline More than 60000 & 26 & 12.5 \\
\hline Total & 208 & 100 \\
\hline \multicolumn{3}{|l|}{ Marital status } \\
\hline Married & 127 & 61.06 \\
\hline Unmarried & 81 & 38.94 \\
\hline Total & 208 & 100 \\
\hline
\end{tabular}


The results have shown that out of total 208 valid respondents, majority of the respondents $(54 \%)$ were male and remaining $(46 \%)$ were female. As consideration of age, about half of the respondents were in between 26-35 group and second largest cluster was 16-25 group. Similarly about 40 percent have masters and above and more than 80 percent respondents have more than bachelor level of education status. Around half of the respondents employed in service sector, 25 percent self-employed and remaining are students. Majority of the respondent (40\%) earn less than 40000 NPR per month and $38 \%$ earn in between of $20000-40000$ NPR. In consideration of marital status, $61 \%$ are married.

Table 3

Frequency of Respondent Gender, Marital Status, and Income with Relation to Preferred Brands of Two Wheelers

\begin{tabular}{|c|c|c|c|c|c|c|c|c|c|c|c|}
\hline \multirow{2}{*}{$\begin{array}{l}\text { Two } \\
\text { wheeler } \\
\text { brands }\end{array}$} & \multicolumn{3}{|c|}{ Gender } & \multicolumn{3}{|c|}{ Marital status } & \multicolumn{5}{|c|}{ Income } \\
\hline & $\sum^{\frac{0}{\pi}}$ & 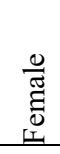 & $\stackrel{\pi}{0}$ & 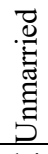 & 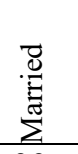 & $\underset{0}{\stackrel{\pi}{0}}$ & 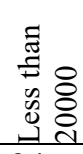 & 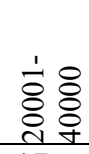 & $\begin{array}{l}1 \\
8 \\
8 \\
8 \\
\\
\end{array}$ & 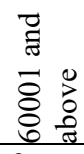 & $\begin{array}{l}\bar{\pi} \\
\stackrel{5}{0} \\
\end{array}$ \\
\hline Bajaj & 30 & 23 & 53 & 14 & 39 & 53 & 24 & 17 & 3 & 3 & 47 \\
\hline Hero & 18 & 9 & 27 & 14 & 13 & 27 & 6 & 11 & 4 & 2 & 23 \\
\hline Honda & 27 & 20 & 47 & 19 & 22 & 41 & 17 & 20 & 7 & 4 & 48 \\
\hline Yamaha & 25 & 13 & 38 & 12 & 26 & 38 & 15 & 12 & 5 & 6 & 38 \\
\hline TVS & 7 & 4 & 11 & 3 & 8 & 11 & 8 & 1 & 6 & 2 & 17 \\
\hline Italjet & 1 & 4 & 5 & 1 & 4 & 5 & 4 & 1 & 0 & 0 & 5 \\
\hline $\begin{array}{l}\text { Royal } \\
\text { Enfield }\end{array}$ & 12 & 1 & 13 & 7 & 6 & 13 & 4 & 4 & 0 & 8 & 16 \\
\hline Others & 4 & 10 & 14 & 11 & 9 & 20 & 7 & 5 & 1 & 1 & 14 \\
\hline Total & 113 & 95 & 208 & 81 & 127 & 208 & 85 & 71 & 26 & 26 & 208 \\
\hline
\end{tabular}

Table 3 reports frequencies of three of the demographic variables gender, marital status, and income status of the respondents and their purchase decisions of various two wheeler brands. The results indicate that male respondents prefer Bajaj, Honda and Yamaha among seven options and same brands stood in top three rank in case of female respondents. However Italijet, TVS and Royal Enfield are less preferred brands by the respondents due to price, quality and other product related reasons. The marital status of the respondents and their purchase decisions seem diverse. The majority of unmarried respondents have purchased Honda, Bajaj, and Hero bikes in more frequency 
respectively and married respondents preferred to buy Bajaj, Yamaha, and Honda bikes more than other brands.

Consequently, the income level of the respondents is found to be another major influencing factor in purchase decision. The result showed that the respondents earning less than 40000 NRS monthly income prefer to by Bajaj, Honda, and Yamaha respectively. The respondents with highest income category preferred Royal Enfield, Yamaha and Honda brands more among available options. Table 4 depicts frequencies of respondents' age, education level, and income level in relation to purchase preference of various two wheeler brands.

Table 4

Frequency of respondent age, education status, and occupation with relation to preferred brands of two wheelers

\begin{tabular}{|c|c|c|c|c|c|c|c|c|c|c|c|c|c|}
\hline \multirow{2}{*}{$\begin{array}{l}\text { Two } \\
\text { wheeler } \\
\text { brands }\end{array}$} & \multicolumn{5}{|c|}{ Age group } & \multicolumn{4}{|c|}{ Education } & \multicolumn{4}{|c|}{ Occupation } \\
\hline & ָิ & în & $\begin{array}{l}n \\
i \\
b \\
n\end{array}$ & $\begin{array}{l}0 \\
0 \\
0 \\
0 \\
\infty \\
0 \\
0\end{array}$ & $\stackrel{\text { 퓽 }}{\varphi}$ & 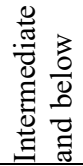 & $\begin{array}{l}\frac{n}{0} \\
\frac{0}{0} \\
\frac{\tilde{J}}{\tilde{I}} \\
\tilde{n}\end{array}$ & 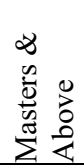 & $\stackrel{\pi}{0}$ & $\begin{array}{l}\overrightarrow{\tilde{D}} \\
\stackrel{\vec{E}}{\vec{E}} \\
\vec{\omega}\end{array}$ & $\begin{array}{c}\stackrel{0}{D} \\
\stackrel{0}{0} \\
\tilde{n}\end{array}$ & $\frac{\overrightarrow{0}}{4} \frac{0}{0}$ & 焉 \\
\hline Bajaj & 30 & 17 & 4 & 1 & 82 & 16 & 15 & 12 & 43 & 24 & 17 & 11 & 52 \\
\hline Hero & 9 & 13 & 2 & 2 & 26 & 4 & 15 & 20 & 39 & 7 & 13 & 7 & 27 \\
\hline Honda & 12 & 31 & 3 & 4 & 50 & 3 & 20 & 15 & 38 & 8 & 36 & 9 & 53 \\
\hline Yamaha & 15 & 19 & 4 & 0 & 38 & 6 & 8 & 25 & 39 & 6 & 22 & 10 & 38 \\
\hline TVS & 3 & 8 & 3 & 0 & 14 & 0 & 9 & 9 & 18 & 3 & 3 & 5 & 11 \\
\hline Italjet & 5 & 0 & 0 & 0 & 5 & 3 & 3 & 0 & 6 & 2 & 0 & 1 & 3 \\
\hline $\begin{array}{l}\text { Royal } \\
\text { Enfield }\end{array}$ & 4 & 6 & 1 & 0 & 11 & 1 & 8 & 6 & 15 & 5 & 3 & 3 & 11 \\
\hline Others & 5 & 7 & 0 & 0 & 12 & 3 & 4 & 3 & 10 & 5 & 4 & 4 & 13 \\
\hline Total & 83 & 101 & 17 & 7 & 208 & 36 & 82 & 90 & 208 & 60 & 98 & 50 & 208 \\
\hline
\end{tabular}

The frequencies displayed in Table 3 have shown remarkable difference in purchasing decision related to two wheeler brands. The most popular brands among 16-25 age group are Bajaj, Yamaha, and Honda respectively. The respondents of working age (between age of 26-35) preferred Honda, Yamaha, and Bajaj respectively. These three top brand preferences also have been reflected by customers of 36-45 age bands. The senior respondent above 45 years of age have shown least purchase intention among all four age categories and Honda, Hero, and Bajaj brand still stood at top of their preference.

The educational status of the respondents also influence purchase preferences of the 
respondents. As per the result shown in Table 3, customers with intermediate and below education mostly preferred Bajaj, Yamaha and Hero brands. However, respondents with bachelor level education selected Honda, Hero and Bajaj brands respectively. Similarly, respondents having masters degree and above education preferred Yamaha, Hero, and Honda brands more among the options. The occupational status of respondents also has discriminated brand preferences for purchase decision. Most of the students participated in the survey preferred Bajaj bikes the most and other brands they have chosen are Honda, Hero, and Yamaha among all. The respondents engaged in service have used Honda, Yamaha, and Bajaj bikes.

Table 5

Study Hypotheses and Chi-Square Statistics of Test of Hypotheses (The Tabulated Value of Chi-Square Denotes Values at 5\% Level of Significance)

\begin{tabular}{|c|c|c|c|c|c|}
\hline $\begin{array}{l}\text { Hypothesis statement/ Chi } \\
\text { square test statistics }\end{array}$ & $\begin{array}{l}\text { Degree of } \\
\text { freedom }\end{array}$ & $\begin{array}{l}\text { Tabulated } \\
\text { Chi square } \\
\text { statistic }\end{array}$ & $\begin{array}{l}\text { Calculated } \\
\text { Chi square } \\
\text { statistic }\end{array}$ & $\mathrm{p}$-value & Decision \\
\hline $\begin{array}{l}\mathrm{H}_{1}: \text { Gender is associated } \\
\text { significantly with purchased } \\
\text { decision of two wheelers. }\end{array}$ & 7 & 14.067 & 22.4 & 0.002 & Accepted \\
\hline $\begin{array}{l}\mathrm{H}_{2} \text { : Age is associated } \\
\text { significantly with purchased } \\
\text { decision of two wheelers. }\end{array}$ & 21 & 32.671 & 55.27 & 0 & Accepted \\
\hline $\begin{array}{l}\mathrm{H}_{3} \text { : has a significant } \\
\text { association with purchased } \\
\text { decision of two wheelers. }\end{array}$ & 14 & 23.685 & 84.22 & 0 & Accepted \\
\hline $\begin{array}{l}\mathrm{H}_{4} \text { : Occupation is associated } \\
\text { significantly with purchased } \\
\text { decision of two wheelers. }\end{array}$ & 14 & 23.685 & 30.165 & 0.007 & Accepted \\
\hline $\begin{array}{l}\mathrm{H}_{5} \text { : Income has a significant } \\
\text { association with purchased } \\
\text { decision of two wheelers. }\end{array}$ & 21 & 32.671 & 36.72 & 0.018 & Accepted \\
\hline $\begin{array}{l}\mathrm{H}_{6} \text { : Marital status is associated } \\
\text { significantly with purchased } \\
\text { decision of two wheelers. }\end{array}$ & 7 & 14.067 & 14.66 & 0.041 & Accepted \\
\hline
\end{tabular}

The results of Table 5 have reported chi square test statistics of six hypotheses statements of the study. The hypothesis one intended to find relation between gender and purchase decision of respondents. The chi-square test of interdependence was performed 
to examine the relation between gender and purchase decision of two wheelers. The relation between these variables was significant $X^{2}(7, N=208)=22.40, p=0.0021$. The tendency of purchasing various brands of bikes is significantly related to customer gender. The brand preferences and purchase tendency of male and female found to be remarkably different with each other.

Consequently, hypothesis two aimed to examine interrelation between age factor of the respondent and their purchase decisions. The result of the chi-square test of independence showed that there was a significant association between respondent age and purchase decision of two wheelers, $X^{2}(21, N=208)=55.27, p=0.0000$. The results have suggested that customers of different age group have shown their brand choice preferences differently as per their requirements. The third study hypothesis examined association between education level and two wheelers brand purchase decisions of the respondents. The chi-square test of interdependence was performed to examine the relation between respondent education level and purchase decision of two wheelers. The relation between these variables was significant $X^{2}(14, N=208)=84.22$, $p=0.0000$. Hence education level significantly affects brand choice and purchase decision.

The fourth hypothesis tested relations between respondent occupation and bike purchase decision. The results of chi-square test of interdependence showed that there was a significant respondent occupation and their purchase decisions, $X^{2}(14, N=208)=30.16$, $p=0.0072$. Different occupation followed by the respondents determining choice of specific brand of two wheelers. Similarly, the chi-square test of interdependence was performed to examine the relation between respondent income level and purchase decision of two wheelers. The relation between these variables was significant $X^{2}(21, N=208)=36.72, p=0.0181$. Finally, in concern of the sixth study hypothesis, the chi-square test of interdependence was performed to examine the relation between respondent marital status and purchase decision of two wheelers. The relation between these variables was significant $X^{2}(7, N=208)=14.66, p=0.0406$.

\section{Conclusion}

This paper intended to examine relation of six demographic characteristics of the respondents; gender, age, education status, occupation, income level, and marital status with their purchase decision regarding various two wheeler brands. The chi square test of interdependence was performed to examine the association respondents' demographic variables and purchase decision. The chi-square test of interdependence was performed to examine the relation between gender and purchase decision of two wheelers. The relation between these variables was significant thus there is a difference between male 
and female consumers on their purchase decision of two wheelers. This is probably due to the differences in requirement of two wheelers of two genders as female consumers prefer low powered scooters and male prefer high and moderate powered bikes.

Similarly, age of the respondents also found significantly associated with purchase decision. The respondents of different age group thus prefer different brands of two wheelers from premium bikes to economy bikes. The education and occupation are also significantly related to purchase decision indicating that consumer's educational level and occupational status determines two wheeler types and then varies purchase decisions. Meanwhile, the associations of income level and marital status with purchase decision are significant. The respondents of different income level have significantly different brand choice from premium to economy segments within various brands. Consequently, marital status also associates significantly with purchase decision. The results are consistent with the literature and most of the previous studies. In conclusion, all six demographic characteristics; with gender, age, education and occupation, income, and marital status have significant influence on purchase decision of two wheeler brands.

\section{References}

Akpinar, G. M., Aykin, S. M., Sayin, C., \& Ozkan, B. (2009). The Role of Demographic Variables in Purchasing Decisions on Fresh Fruit and Vegetables. Journal of Food Agriculture and Environment, 7 (3 \& 4), 106-110.

Chauhan, N. (2103). Consumer Behaviour and his Decision of Purchase. International Journal for Research in Management and Pharmacy , 2 (5), 1-4.

Cheong, H. (2016). Purchase Decision Type Influences on Consumers' Reliance:Brandrelated user generated content. Knoxville: University of Tennessee.

Hassani, I. (2018). The relationship between demographics and consumers' propensity for rewarding or punishing a company based on social responsibility. Ontario, Canada: University of Waterloo.

Leila, H., \& Zohra, B. (2018). The Impact Of Demographic Factors on the. International Journal of Academic Research in Business and Social Sciences , 8 (5), 616-627.

Mastaran, S. (2017). Determinants of Brand choice of two wheelers in Kathmandu Valley. The International Research Journal of Management Science , 2 (1), 91105.

Puska, A., Stojanović, I., Sadic, S., \& Becic, H. (2018). THE INFLUENCE OF DEMOGRAPHIC CHARACTERISTICS OF. Journal of Aplied Economics , 15 (2), 1-16. 
Puska, A., Stojanovic, I., Sadic, S., \& Becic, H. (2018). The Influence of Demographic Characteristics of Consumers on Decisions to Purchase Technical Products. 15 (2), 1-16.

Rahim, R. A., Sulaiman, Z., Chin, T. A., Arfi, M. S., \& Hamid, M. H. (2017). Consumers' demographic profile influence on green purchase intention. IOP Conference Series: Materials Science and Engineering. 215, pp. 1-6. IOP Publishing.

Sheik, M. A., \& Ali, M. E. (2013). An analysis of the factors influencing the buyers of passanger cars. International Journal of Economics, Commerce and Research , 3 (5), 73-82.

Vilcekova, L., \& Sabo, M. (2013). The influence of demographic factors on attitudes toward brands and brand buying behavior of Slovk consumers. International Journal of Education and Research , 1 (11), 1-10.

Weerasiri, R. A., \& Mendis, A. (2015). Factors affecting purchase decision for Indian two wheelers in Sri Lankan market. Kelaniya Journal of Management , 4 (2), $10-22$. 